\title{
Variability in the settlement of non-indigenous species in benthic communities from an oceanic island
}

\author{
Léa Riera ${ }^{1,2^{*}}$ (D), Patrício Ramalhosa ${ }^{2,3}$, João Canning-Clode ${ }^{2,4,5}$ and Ignacio Gestoso ${ }^{2,5}$
}

\begin{abstract}
The introduction of non-indigenous species (NIS) in new environments represents a major threat for coastal ecosystems. A good understanding of the mechanisms and magnitude of the impact of NIS colonisation on native ecosystems is becoming increasingly crucial to develop mitigation measures and prevent new invasions. In this present study, we asked if distinct coastal benthic communities from an oceanic island can have different vulnerability to NIS colonisation process. First, PVC settlement plates were deployed for 1 year on the rocky shore of two different locations of Madeira Island (North versus South coast). Then, we implemented a mesocosm experiment where recruited plate communities were maintained under different levels of NIS propagule pressure in order to assess their vulnerability to NIS colonisation process. Results showed that NIS colonisation success was not influenced by the level of propagule pressure, but however, final colonisation patterns varied depending on the origin of the communities. This variability can be attributed to major structural differences between the preponderant species of each community and therefore to the biotic substrate they offer to colonisers. This study highlights how biotic features can alter the NIS colonisation process and importantly, shows that in an urbanisation context, the nature of the resident communities facing invasions risks needs to be closely assessed.
\end{abstract}

Keywords: Invasion, Island, Non-indigenous species, Mesocosm, Propagule

\section{Background}

The introduction and spread of non-indigenous species (NIS) causing biological invasions is, along with habitat destruction, considered as a major cause of biodiversity loss worldwide [1, 2]. In fact, biological invasions have recently been considered the second most significant driver of species extinctions [3] and future climate change is predicted to increase the spread of invasive species, accelerating invasions [4].

Non-indigenous species can thus modify ecosystems by displacing native species, altering habitat characteristics and modifying nutrients, food, light and space availabilities [5]. The impact of NIS on native communities and ecosystems have been increasingly studied for decades [6],

\footnotetext{
*Correspondence: riera.lea31@gmail.com

${ }^{2}$ MARE - Marine and Environmental Sciences Centre, Quinta do Lorde Marina, Sítio da Piedade, 9200-044 Caniçal, Madeira Island, Portugal
} Full list of author information is available at the end of the article making invasion biology a young and rapidly developing discipline with broad ecological and conservation implications [1]. Criteria used to categorise a species as invasive remains somewhat controversial, but invaders can be characterised as NIS that undergo rapid increases in abundance and/or spatial occupancy with adverse effects on recipient ecosystems [7]. Other definitions specify that the introduction of these species outside of their natural dispersal potential must be caused by human action, whether intentionally or unintentionally [8].

Nowadays, global human activities are facilitating and accelerating the movement of many species [9] and the proportion of documented invasions has significantly increased in the last two decades [10]. Particularly in the marine system, over 1500 species have invaded locations throughout the world's oceans, and new detections are found every year at a global scale [11]. Even though the increase in biological invasion reports is likely to be influenced by the associated increase in search efforts, it 
is commonly admitted that invasions have been largely facilitated by the increase of worldwide marine traffic through the transport of fouling species on vessel hulls and through ballast water [12]. The surge of marine debris rafting through entire oceans is also able to carry fouling species for long distances and is now being considered as a significant vector of NIS introduction worldwide [13, 14]. Fouling organisms are characterised by their ability to attach, accumulate and colonise hard artificial substrates [15-17]. Anthropogenic areas such as marinas and ports experience the most intense input of fouling species due to high marine traffic [18]. The main fouling species found around the world are usually macroalgae, sponges, hydroids, polychaetes, barnacles, molluscs and tunicates $[19,20]$. The fouling process is complex and highly depends on the ability of the larvae to find a bare substrate or invade an already occupied substrate and obtain adequate resources [21]. Moreover, expanded tourism in coastal regions has undoubtedly led to an increasing number of anthropogenic structures that can be used by fouling organisms as a longterm substrate [22]. Moreover, coastal urbanisation is also often accompanied with important changes of local physico-chemical conditions (i.e. lower salinity, pollutant concentration, currents and waves changes) which are all characterised as disturbances for coastal ecosystems $[23,24]$. When such disturbed habitats are combined with high and frequent inputs of NIS, as it is the case in harbours and marinas, this combination increases the opportunity of invasion, and therefore the risk of colonisation of adjacent established communities [25]. In this context, fouling communities have been used in several ecological studies investigating marine invasions [26-28] as they are easy to collect and develop rapidly.

Furthermore, various biological mechanisms influence marine invasion success such as negative interactions, positive interactions, invader traits or post-invasion evolution [29]. Each of these aspects requires further research to obtain a broader understanding of the global invasion process. Whether in terrestrial or marine environments, the invasion process depends on several characteristics associated with the non-indigenous organisms (i.e. invasiveness), the features of the recipient community (i.e. invasibility) and also on propagule pressure [30]. The term 'propagule pressure' usually involves, not only the abundance of individuals arriving into an area (propagule size), but also the frequency at which they arrive (propagule frequency) [31]. While several studies have demonstrated a positive relationship between propagule pressure and establishment success [32-34] little is known about the nature of this relationship [35, 36]. However, just as some NIS are more successful invaders than others, some communities are more susceptible to invasions [26]. For example, a higher predominance of invasions has been reported in disturbed ecosystems and for communities with low species diversity [37]. Moreover, island intertidal ecosystems are usually more sensitive to invasions due to the lack of competitors and are therefore more likely to have "open" niches and to suffer severe impacts from invasions [26].

The Madeira archipelago is located in the north-eastern Atlantic Ocean, $700 \mathrm{~km}$ off the Moroccan coast and has historically provided a major rest-stop for boats crossing the Atlantic between Europe, the Americas and Africa [38]. Today, most of Madeira's maritime traffic comes from tourist cruise ships and yachts for re-fuelling, and tourism [39]. The number of NIS detections in the archipelago has been increasing in recent years due to ongoing monitoring surveys and biodiversity assessments around the Madeira island system [40-42]. These recent studies suggest that most NIS arriving in Madeira are likely from other European ports, particularly in the Mediterranean and Northern Europe, and are conveyed by secondary or tertiary introduction vectors $[19,43]$. Furthermore, a recent local investigation, conducted at the same marina where the present study was performed, confirmed a positive relationship between the number of vessels arriving at that particular marina and the cumulative number of NIS detected during the survey period [19]. The South coast of Madeira is particularly exposed to human activities (e.g. ship traffic, urbanisation, aquaculture and coastal development) which can cause local geographic expansion of several NIS through the dispersion of propagules from marinas to the rest of the island's South coast [23]. In contrast, the North coast of the island, perhaps due to its abrupt coastline, is less subjected to anthropogenic pressures. Moreover, significant differences in hydrodynamic and weather conditions between the northern and southern coasts have been described [44, 45]. Nonetheless, to date no study has investigated whether differences between North and South intertidal benthic ecosystems can influence their vulnerability to NIS colonisation in Madeira.

In the present study, we firstly investigated the typical species composition of intertidal benthic communities from different locations along the North and South coasts of Madeira Island. In parallel, we employed a settlement plate methodology to collect artificial communities from the North and South coasts throughout one year. We then used a mesocosm system to maintain these plate communities under different levels of NIS pressure and evaluate the NIS colonisation success across two "biotic substrates" i.e. benthic plate communities. We hypothesised that communities from the North versus South coast will differ and this variability will induce different colonisation success depending on the benthic 
community. Specifically, we expect Southern communities to be more susceptible to NIS colonisation due to higher disturbance of their environment. In addition, we simulated two different levels of NIS pressure in order to test the consistency of the responses under different potential invasion scenarios.

\section{Methods}

Preliminary study: comparison of benthic communities in the North and South coasts

We compared benthic communities at the northern and southern coasts of Madeira Island to investigate whether these communities differ in terms of species composition. This was a prerequisite that would allow us to consider two different community types that would be represented when collecting field samples both on the North and South coasts of the island. This study consisted of comparing field quadrate photos of low intertidal benthic communities in six locations (Fig. 1) from northern $(\mathrm{N})$ and southern $(\mathrm{S})$ coasts of Madeira Island, namely Seixal (N), Rocha do Navio (N), Porto Moniz (N), Reis Magos (S), Quinta do Lorde (S), and Riberia Brava (S). In each location, 10 photos of a $20 \times 20 \mathrm{~cm}$ delimited quadrate were recorded (Canon EOS 30D) at the low shore (i.e. $0.4-0.8 \mathrm{~m}$ above the lowest astronomical tide) and then analysed with the Coral Point Count software (CPCe 4.1) [46] to assess species composition and their cover-abundance for each quadrate. Each image was subdivided into a $3 \times 3$ grid of 9 cells, with 11 random points per cell resulting in 99 points analysed per image. This stratified random sampling method ensured that points were sampled in each section of the image [46].

\section{Field collections of NIS}

In June 2013, a total of 32 bricks to be colonised by fouling communities were deployed in Funchal marina $\left(32^{\circ} 38^{\prime} \mathrm{N}, 16^{\circ} 54^{\prime} \mathrm{W}\right)$, the marina with the highest vessel traffic to be colonised by fouling communities. These bricks were mostly assembled by NIS and to be later used as a proxy to simulate high NIS propagule pressure conditions inside the mesocosm tanks. Bricks were randomly deployed in the marina, tightened to a rope and vertically attached to the pontoons at approximately $1 \mathrm{~m}$ depth. Almost four years later, in May 2017, the bricks were collected and kept in plastic buckets filled with seawater to facilitate transportation. At the laboratory, a qualitative survey of the organisms attached to each brick was conducted by the naked eye. In addition, photographs were taken at the six faces of each brick to complete the survey by image analysis. For each brick, fouling species were identified to the lowest taxonomic group based on existing literature or by consulting taxonomic experts. Finally, all sessile macroinvertebrates and macroalgae colonising bricks were assigned to one of three categories: native, NIS, or cryptogenic (i.e. unspecified or unknown origin). This biogeographic categorisation was based on available literature and databases [47-49].
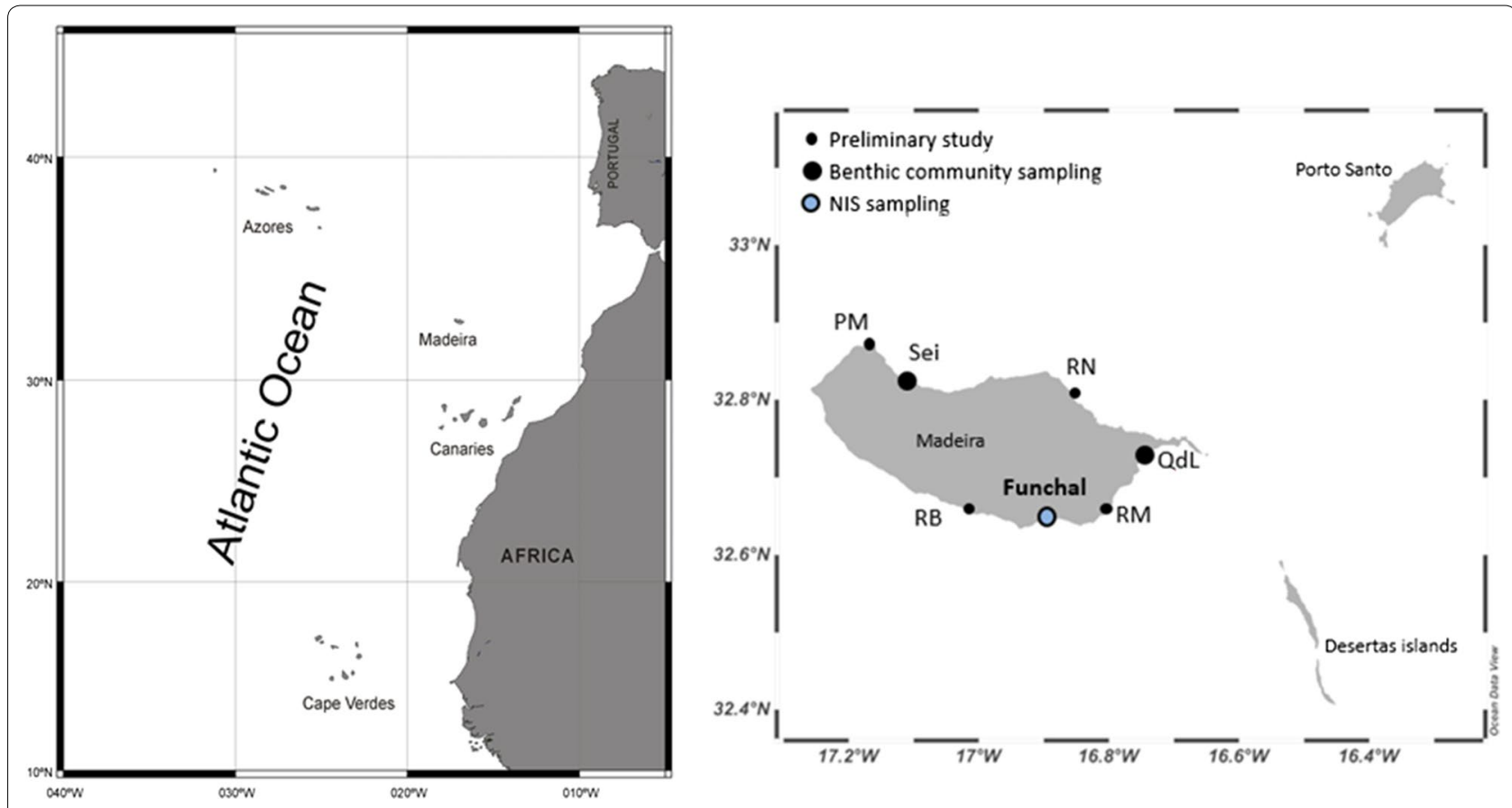

Fig. 1 Map of the study area showing Madeira archipelago in the Atlantic Ocean and the sites of the preliminary study as well as the sampling sites 


\section{Field collections of benthic communities}

In addition, a total of 36 polyvinylchloride (PVC) plates were installed at two different locations to allow colonisation by resident species. Eighteen PVC plates $(14 \times 14 \times 0.3 \mathrm{~cm})$ were deployed in May 2016 near Quinta do Lorde Hotel beach (Qdl) located in the South coast $\left(32^{\circ} 44^{\prime} 30.3^{\prime \prime} \mathrm{N} 16^{\circ} 42^{\prime} 31.9^{\prime \prime} \mathrm{W}\right)$ and eighteen additional plates at Seixal beach (Sei) located in the North coast $\left(32^{\circ} 49^{\prime} 34.2^{\prime \prime} \mathrm{N} 17^{\circ} 07^{\prime} 07.5^{\prime \prime} \mathrm{W}\right)$ (Fig. 1). Plates were individually drilled into low intertidal rocky shores using stainless steel screws approximately $1 \mathrm{~m}$ from the lowest tide transect, keeping the same orientation and height. After allowing 12 months of colonisation, settlement plates were then retrieved from the field and kept in separate plastic bags filled with seawater to avoid degradation during transport to the laboratory. Each plate was carefully examined by a stereo-microscope (Leica S8 APO) and then photographed to be later analysed with $\mathrm{CPCe}$ in order to assess species composition (richness and abundance) of each plate by employing the method previously described.

\section{Mesocosm experiment}

The experiment lasted 60 days (26th May to 25th July 2017) and was conducted at the facilities of the Marine and Environmental Research Centre (MARE) at the Quinta do Lorde Marina, located on the southeast coast of Madeira Island $\left(32^{\circ} 44.5^{\prime} \mathrm{N}, 16^{\circ} 42.8^{\prime} \mathrm{W}\right)$. The mesocosm system used 6 independent PVC tanks, each with $350 \mathrm{~L}$ of volume, filled with $10 \mu \mathrm{m}$ filtered-seawater directly sourced from the marina. A literature review has been carried out to verify that the propagules of the species found on the bricks were larger than $10 \mu \mathrm{m}$ and ensured that no recruitment from outside the mesocosm was possible. A continuous water flow of $20 \mathrm{ml} / \mathrm{s}$ was kept during the whole duration of the experiment, resulting in a complete turn-over of the water in each tank approximately four times a day. In addition, constant aeration was installed in each tank. The whole system received natural light under an approximate 12/12 h light/dark photoperiod.

The experiment consisted of a $3 \times 3$ factorial design to test how benthic communities from different locations (fixed, three levels: northern communities, southern communities and un-colonised control plates) react to different levels of propagule pressure (fixed, three levels: none, low, high). The three "propagule pressure" treatment scenarios were simulated by suspending 0 (ambient pressure), 4 (low pressure) and 8 (high pressure) bricks completely colonised by fouling species in the tanks. Moreover, in the "high" treatment tanks, an additional 4 bricks were added halfway through the experiment total duration (i.e. +30 days) to differentiate the frequency of introduction between the two treatments. These three levels intended to perform as a proxy for simulating the environmental scenarios during the development of a harbour facility in a coastal rocky shore. Indeed, in the control tanks, communities were already facing some of the associated environmental disturbances, such as water quality deterioration compared to natural conditions due to sourcing of the water from the marina or the absence of wave action and currents existing in their natural environment [24]. These conditions intended to represent the environmental changes observed at the initial stage of a coastal urbanisation project, and the addition of bricks in the two propagule pressure treatments could indicate further development with the arrival of boats and ships to the area (Fig. 2).

Each treatment was replicated in two randomly-positioned tanks to prevent tank effects during the analysis and PVC plates $(\mathrm{N}=54)$ were placed at the bottom of the tank. Three replicates of each plate community (North, South, control) were randomly assigned to each tank. Temperature was continuously monitored using dataloggers (HOBO pendant temp/light, 64 k UA-002-064; Onset Computer Corporation, Bourne, MA, USA) set to measure temperature every $30 \mathrm{~min}$. Salinity, $\mathrm{O}_{2}$ and $\mathrm{pH}$ were measured and kept constant during the experiment (Temperature $=20.8 \pm 0.3{ }^{\circ} \mathrm{C}, \mathrm{O}_{2}$ concentration $=6.5 \mathrm{mg}$. $\mathrm{mL}^{-1}, \mathrm{pH}=7.95$, salinity $=30.06 \mathrm{ppt}$ ). Each tank was cleaned once a week by siphoning the bottom sediments. Regarding the fouling species identified on the bricks and based on literature [50,51], a microalgae diet was chosen. Animals were fed every $48 \mathrm{~h}$ with a mixture of four species of phytoplankton: Nannochloropsis sp., Chlorella sp., Isochrysis sp. and Rhodomonas sp. at $50.10^{6}$ cells/ $\mathrm{mL}$. Fresh cultures were provided weekly by the Oceanic Observatory of Madeira and kept in bottles with air supply and light. At each feeding session, $200 \mathrm{ml}$ of the mixture was added to each tank with the water-flow turned off for three hours after feeding to allow enough feeding time.

At the end of the experiment, all plates were analysed using the same identification methods, to identify all species settled and assess species cover in order to evaluate every potential change in the species composition and the variability in the patterns of NIS colonisation success across the different plate communities.

\section{Data analyses \\ Preliminary study}

The hypothesis tested here is that communities from the North and South coasts are different using the quadrates photos analysis. Both univariate (species diversity) and multivariate (percent cover of each species) analysis 


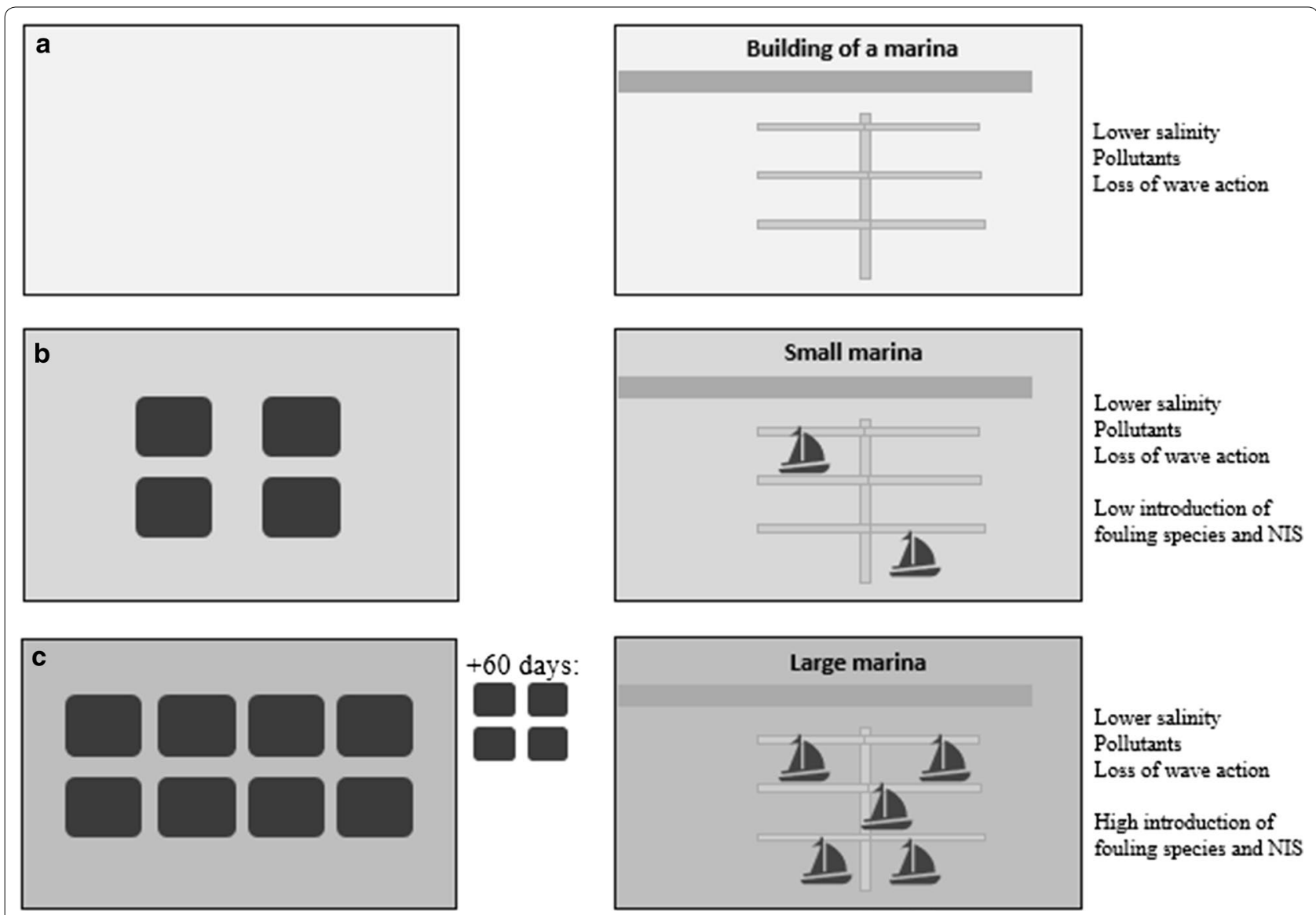

Fig. 2 Illustration of the experimental design: 3 NIS pressure (a control, b low, $\mathbf{c}$ high) to represent in the mesocosm three scenarios: a building of a marina and perturbation of the ecosystem; $\mathbf{b}$ mall marina, start of NIS introduction; c large marina, important NIS introduction)

were performed. A one-factor (Location) orthogonal non-parametric permutational analysis of variance (PERMANOVA) on square-root transformed data was used as well as a 2-sample $t$ test to verify our hypothesis. Furthermore, to visualise multivariate patterns between North and South coast communities, a non-metric multidimensional scaling (nMDS) was employed to generate a twodimensional ordination plot.

\section{Mesocosm experiment: analysis of the collected communities} Prior to the mesocosm experiment, communities collected on plates deployed in the field were analysed in terms of species composition and percent cover, to ensure that they represent significantly different communities and therefore reflect what has been observed during the preliminary study. Fouling species composition on the bricks collected in Funchal marina was compared using a one-factor PERMANOVA analysis to ensure that there were no statistical differences of fouling species composition between tanks after a random brick distribution among tanks and to investigate the difference of species diversity collected on plates from Quinta do Lorde (South coast) and Seixal (North coast). A nonmetric multidimensional scaling (nMDS) was then used to visualise this difference. Species that mostly contributed to the dissimilarity between the two groups were identified using SIMPER analysis [52].

\section{Mesocosm experiment: analysis of the final composition}

Several hypotheses were tested here. First, the impact of the pressure treatments on the different communities was analysed to assess if a higher NIS pressure during the experiment provokes a higher final colonisation. Second, the results of each community among each treatment was examined to verify if they respond differently to NIS pressure. A PERMANOVA analysis on data from percent cover of all species found on the plates at the end of the experiment was carried-out. Significant effects $(p<0.05)$ were further investigated through pairwise comparisons between treatments. When the random factor "Tank" was non-significant at level $p>0.25$, tanks were pooled [53] and PERMANOVA and ANOVA analyses were 
re-run $(n=6)$. To graphically visualise multivariate patterns of variation among communities associated with treatments, nMDS was used to produce two-dimensional ordination. Finally, species abundance differences between the start and the end of the experiment were also compared using ANOVA on the same model used for PERMANOVA and taxa that mostly contributed to the dissimilarity were identified using SIMPER analysis.

PERMANOVA, ANOSIM and SIMPER analyses were performed using the PRIMER 6 software package with the PERMANOVA extension $[54,55]$. ANOVA was performed using $\mathrm{R}$ and the 'Im' function in the base package [56].

\section{Results}

Preliminary study: comparison of North vs South benthic communities

A total of 18 species were identified in the field quadrate photos from the North and the South of the island and percent cover of all species were assessed (Table 1). nMDS revealed a clear segregation between the communities from northern and southern stations (Fig. 3). In addition, the results of the PERMANOVA analysis on the initial composition of the plates used for the experiment confirmed that North and South plates were significantly different in community composition $(p=0.003)$. Plates from the South were covered at $48 \%$ by algae from the Corallinae family, characterised by calcareous cell walls and hard thallus, typically encrusting rocks and boulders of the intertidal zone (i.e. crustose coralline algae, CCA). On the other hand, plates collected in the North, only $3 \%$ of the plates were covered with Corallinae algae, but about $40 \%$ of the surface were colonised by an undifferentiated algae turf composed mainly of Gelidium sp. and Polysiphonia sp. This result confirmed that by working with communities from the North and South of the island, we were indeed comparing two different types of coastal benthic communities (i.e. CCA vs. turf). Moreover, a two-sample $t$ test $(\mathrm{df}=119 ; \mathrm{t}=-1.71 p=0,045)$ showed that Southern communities presented higher diversity (average total species $( \pm \mathrm{SE}) \mathrm{S}=5.6 \pm 0.32$, $\mathrm{n}=18)$ than Northern communities $(\mathrm{S}=4.4 \pm 0.24$, $\mathrm{n}=18$ ). Finally, difference in bare space present on the plates at the start of the experiment was not significant $(\mathrm{N}=1.52 \% \pm 0.23 ; \mathrm{S}=0.86 \% \pm 0.19)$.

\section{Recruitment of communities in bricks and plates}

In total, 43 species were identified on the brick communities (Table 2), mostly dominated by ascidians (10), polychaetes (8), bryozoans (7) and sponges (5). Based on available literature and databases, we categorised $41 \%(18 / 44)$ of these organisms as being NIS. Bricks were randomly assigned to the treatment tanks and a PERMANOVA analysis showed no significant differences between species distribution in the tanks (Pseudo$\mathrm{F}_{3,20}=0.719, \mathrm{P}($ perm $\left.)=0.838\right)$. With this result, we

Table 1 Average percentage $( \pm S E)$ of the species identified on the quadrate photos from North and South sites $(n=60)$

\begin{tabular}{|c|c|c|c|}
\hline Taxa (South) & $\%$ cover & Taxa (North) & $\%$ cover \\
\hline Algae & & Algae & \\
\hline Corallina algae & $49.1 \pm 3.8$ & Gelidium and Polysiphonia turf & $45.5 \pm 4.3$ \\
\hline Gelidium and Polysiphonia turf & $12.5 \pm 1.4$ & Codium adhaerens & $21.0 \pm 4.0$ \\
\hline Codium adhaerens & $11.6 \pm 3.0$ & Asparagopsis sp. & $16.1 \pm 4.1$ \\
\hline Corallina crust (CCA) & $4.0 \pm 1.9$ & Corallina crust (CCA) & $5.9 \pm 1.5$ \\
\hline Rivularia sp. & $2.5 \pm 1.0$ & Corallina algae & $3.0 \pm 1.1$ \\
\hline Asparagopsis sp. & $1.8 \pm 1.2$ & Chrysymenia sp. & $0.2 \pm 0.1$ \\
\hline Gracilaria sp. & $1.7 \pm 1.0$ & Gracilaria sp. & $0.9 \pm 0.4$ \\
\hline Laurencia pinnatifida & $1.3 \pm 0.8$ & Colpomenia sinuosa & $0.8 \pm 0.4$ \\
\hline Dictyota sp. & $1.2 \pm 0.8$ & Dictyopteris sp. & $0.7 \pm 0.4$ \\
\hline Dictyopteris sp. & $1.0 \pm 0.5$ & Porphyra sp. & $0.4 \pm 0.2$ \\
\hline Padina pavonica & $0.2 \pm 0.1$ & Dictyota sp. & $0.3 \pm 0.2$ \\
\hline Colpomenia sinuosa & $0.1 \pm 0.01$ & Enteromorphasp. & $0.2 \pm 0.1$ \\
\hline Crustacea & & Padina pavonica & $0.2 \pm 0.1$ \\
\hline Chtamalus stellarus & $0.6 \pm 0.3$ & Rivularia sp. & $0.2 \pm 0.1$ \\
\hline Mollusca & & Crustacea & \\
\hline Patella sp. & $0.1 \pm 0.1$ & Chtamalus stellatus & $0.6 \pm 0.3$ \\
\hline \multirow[t]{3}{*}{ Inorganic (bare, silt) } & $12.1 \pm 3.5$ & Mollusca & \\
\hline & & Patella sp. & $0.1 \pm 0.1$ \\
\hline & & Inorganic (bare, silt) & $4.1 \pm 2.0$ \\
\hline
\end{tabular}




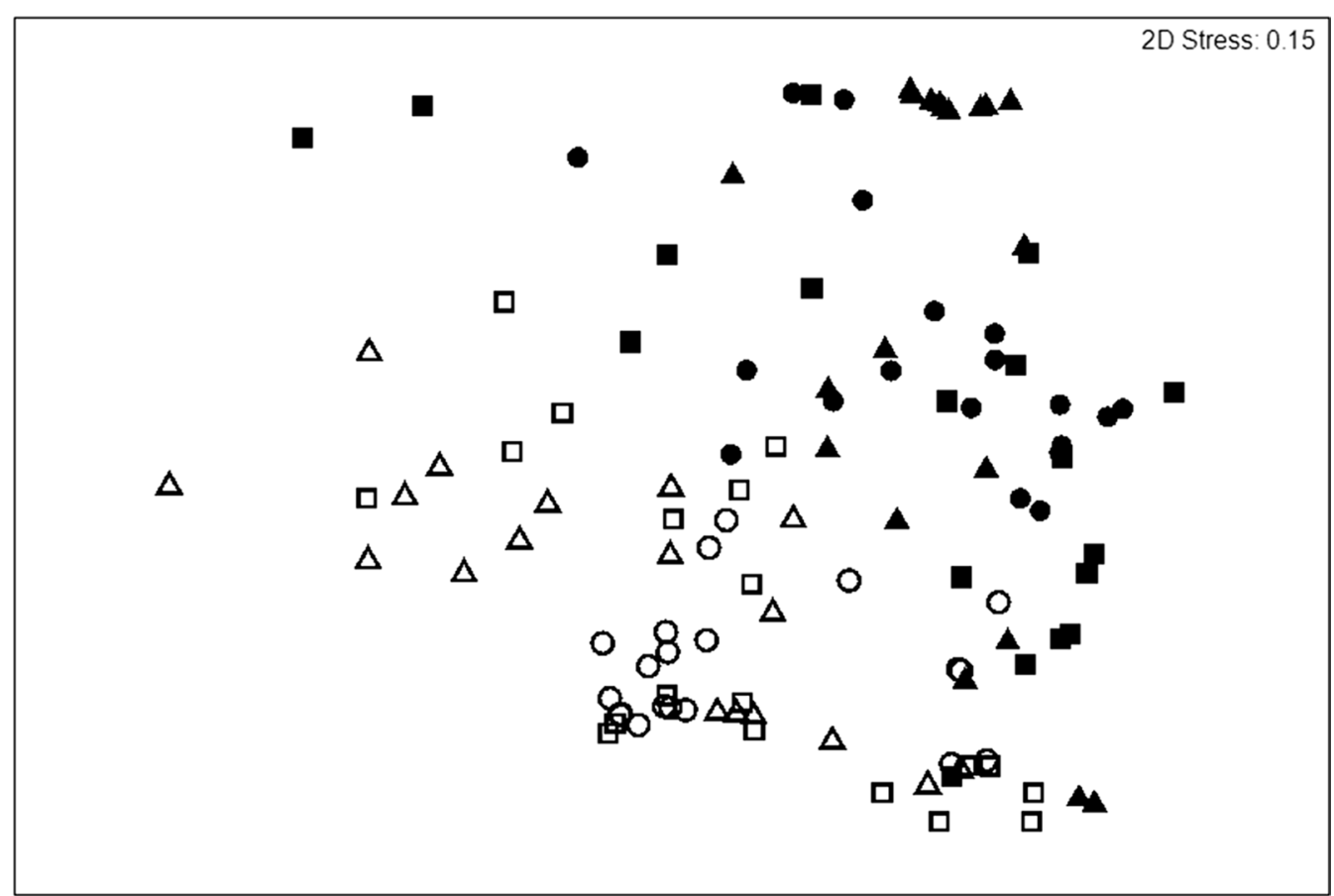

$\begin{array}{ll}\Delta \mathrm{PM}(\mathrm{N}) & \Delta \mathrm{QdL}(\mathrm{S}) \\ \text { - Se (N) } & \text { 口 RM (S) } \\ \text { - PC (N) } & \text { O RB (S) }\end{array}$

Fig. 3 Non-metric multidimensional scaling (nMDS) plot for the preliminary study, using species percentage cover of field quadrate photos of benthic communities found in 6 sites in the North (filled symbols) and 6 sites in the South (empty sumbols) and analysed with Coral Point Count $(n=60)$. 2 sites were considered in each location: Porto Moniz (PM), Seixal (Se), Porto da Cruz (PC), Quinta do Lorde (QdL), Reis Magos (RM) and Riveira Brava (RB)

ensured that the same fouling species and NIS were introduced in all treatment tanks both quantitively and qualitatively.

Based on the species distribution of the PVC plates from North and South coasts of Madeira Island conducted immediately after the field collection, the MDS analysis showed a clear dissimilarity between the two groups of plate communities. This result has been confirmed by a permutational routine showing a significant effect of the factor "location" $(p=0.001)$ whereas "treatment" factor (i.e. tank distribution) $(p=0.738)$ as well as the interaction between the two factors $(p=0.199)$ were not significant. A further analysis of the most relevant species contributing to this dissimilarity showed that North plates were on average mainly covered by Polysiphonia sp. (Rhodomelaceae) and Gelidium sp. (Gelidiaceae) turfs whereas South plates have been mainly colonised by crusting algae like Lithophyllum incrustans (Corallinae) and Nemoderma tingitanum (Nemodermataceae) (SIMPER analysis, Table 3). This result showed consistency between the natural communities characterised in the preliminary study and the artificial communities collected on the plates, validating therefore this approach to be used as proxy communities during the mesocosm experiment.

\section{Mesocosm experiment}

The PERMANOVA and ANOVA results comparing the plate's species composition and number of NIS respectively at the end of the experiment showed in the first place that among each treatment, there was no significant difference between the two tanks with the same propagule pressure (PERMANOVA: Pseudo- $\mathrm{F}_{3,37}=0.924$, $\mathrm{P}($ perm $)=0.498$; ANOVA: $\left.\mathrm{F}_{3,37}=0.555, p=0.585\right)$, which therefore allowed us to re-run the analysis without this factor in the model.

A total of 5 NIS have been identified on the plates displayed in the treatment tanks whereas no NIS were found in the control tanks. At the end of the experiment, the analysis of the differences in composition by PERMANOVA showed that both propagule pressure treatment and the plates origin had a significant impact on the colonisation extent of plates by NIS, but with no interaction between the two factors (Table 4). Pair-wise 
Table 2 Fouling species found colonizing bricks deployed at Funchal marina for almost four years and used in this study as a proxy for propagule pressure source

\begin{tabular}{|c|c|c|c|}
\hline Taxa & Status & $\begin{array}{l}\text { Number of bricks } \\
\text { where observed }\end{array}$ & References \\
\hline \multicolumn{4}{|l|}{ Mollusca } \\
\hline Chiton sp. & U & 6 & \\
\hline Vermetidae & U & 2 & \\
\hline \multicolumn{4}{|l|}{ Algae } \\
\hline Enteromorpha sp. & U & 7 & \\
\hline Lithophyllum incrustans & N & 18 & Canning-Clode et al. [19] \\
\hline Polysiphonia sertulariodes & $\mathrm{N}$ & 5 & Neto et al. [70] \\
\hline \multicolumn{4}{|l|}{ Arthropod } \\
\hline Amphipods & U & 32 & \\
\hline Balanus trigonus & NIS & 18 & Carlton et al. [71] \\
\hline Caprella scaura & NIS & 32 & Ramalhosa and Canning-Clode [72] \\
\hline \multicolumn{4}{|l|}{ Cnidarian } \\
\hline Aiptasia diaphana & NIS & 16 & Canning-Clode et al. [19] \\
\hline Barentsia discreta & $U$ & 3 & \\
\hline Ectopleura sp. & $U$ & 3 & \\
\hline Obelia sp. & U & 7 & \\
\hline Pennaria disticha & $\mathrm{N}$ & 2 & Goldfuss [73] \\
\hline Kirchenpaueria halecioides & C & 12 & $\begin{array}{l}\text { Delivering Alien Species Inventories Europe } \\
\text { website (consulted 01/02/2018) }\end{array}$ \\
\hline \multicolumn{4}{|l|}{ Porifera } \\
\hline Haliclona sp. & U & 1 & \\
\hline Mycale (Carmia) cf. senegalensis & NIS & 13 & Canning-Clode et al. [19] \\
\hline Paraleucilla magna & NIS & 9 & Canning-Clode et al. [19] \\
\hline Prosuberites longispina & U & 4 & \\
\hline Sycon sp. & U & 10 & \\
\hline \multicolumn{4}{|l|}{ Bryozoan } \\
\hline Amanthia verticillata & NIS & 7 & Wirtz and Canning-Clode [74] \\
\hline Bugula neritina & NIS & 17 & Ryland [75] \\
\hline Bugulina fulva & NIS & 4 & Ramalhosa et al. [76] \\
\hline Cradoscrupocellaria bertholletii & NIS & 14 & Canning-Clode et al. [19] \\
\hline Crisia denticulata & $\mathrm{N}$ & 25 & Gestoso et al. [41] \\
\hline Parasmittina alba & NIS & 1 & Canning-Clode et al. [19] \\
\hline Schizoporella errata & C & 23 & Ramalhosa, unpublished \\
\hline \multicolumn{4}{|l|}{ Polychaete } \\
\hline Branchiommabairdi & NIS & 19 & Ramalhosa et al. [77] \\
\hline Lepidonotus clava & U & 1 & \\
\hline Nereididae & U & 1 & \\
\hline Protula tubularia & C & 6 & \\
\hline Salmacina dysteri & $\mathrm{N}$ & 25 & Gestoso et al. [78] \\
\hline Spirobranchus triqueter & N & 19 & Gestoso et al. [78] \\
\hline Spirorbis marioni & NIS & 17 & Knight-Jones and Knight-Jones [79] \\
\hline \multicolumn{4}{|l|}{ Ascidian } \\
\hline Aplidium glabrum & NIS & 5 & Ramalhosa, unpublished \\
\hline Botrylloides nigrum & NIS & 9 & Gestoso et al. [41]; Ramalhosa, unpublished \\
\hline Botryllus schlosseri & NIS & 8 & Canning-Clode et al. [19] \\
\hline Clavelina lepadiformis & NIS & 9 & Wirtz [80]; Canning-Clode et al. [19] \\
\hline Distaplia corolla & NIS & 4 & Canning-Clode et al. [19] \\
\hline
\end{tabular}


Table 2 (continued)

\begin{tabular}{llll}
\hline Taxa & Status & $\begin{array}{l}\text { Number of bricks } \\
\text { where observed }\end{array}$ & References \\
\hline Ectenascidia sp. & U & 4 & Wirtz [80]; Ramalhosa, unpublished \\
Phallusia mamillata & N & 1 & Canning-Clode et al. [19] \\
Styela canopus & NIS & 25 & Gestoso et al. [41]; Ramalhosa, unpublished \\
Symplegma brakenhielmi & C & 3 & Canning-Clode et al. [19] \\
Trididemnum cereum & N & 4 & \\
\hline
\end{tabular}

The biogeographic status of each species (NIS: non-indigenous species, N: Native, C: Cryptogenic, U: Undetermined) as well as the frequency it has been found on the bricks

Table 3 Results of the SIMPER analysis comparing main species abundance on PVC plates and showing the dissimilarities $(\delta i)$ and the contribution of the different species ( $\delta i \%)$

\begin{tabular}{|c|c|c|c|c|c|}
\hline \multirow[t]{2}{*}{ Taxon } & \multicolumn{2}{|c|}{ Av.Abund } & \multirow[t]{2}{*}{$\delta i$} & \multirow[t]{2}{*}{$\delta \mathrm{i} / \mathrm{SD}$} & \multirow[t]{2}{*}{$\delta i \%$} \\
\hline & North & South & & & \\
\hline Polysiphonia sp. & 48.65 & 0 & 24.62 & 1.38 & 29.55 \\
\hline Lithophyllum incrustans & 2.24 & 39.5 & 19.49 & 1.07 & 23.39 \\
\hline Nemoderma tingitanum & 15.94 & 39.71 & 17.12 & 1.41 & 20.55 \\
\hline Gelidium sp. & 25.2 & 3.88 & 12.19 & 0.86 & 14.63 \\
\hline
\end{tabular}

PERMANOVA tests were performed for the two factors propagule pressure and plates origin, and results showed that NIS colonisation associated with both propagule pressure treatments (High and Low) were significantly different from the ambient pressure (control treatment) (Pairwise tests, Table 4), but there was no significant difference between High and Low propagule pressure treatments (Pairwise tests, Table 4). However, NIS colonisation of the plates from North and South coasts differed significantly and there was no difference between colonisation of South plates or control plates (Fig. 4).

Moreover, at the end of the experiment the most common NIS found on the plates were Aiptasia diaphana (Cnidaria), Mycale (Carmia) senegalensis (Porifera) and Crisia cf. denticulata (Bryozoa). For both pressure level, we found that plates from South and control plates received higher NIS colonisation than plates from the North (Fig. 5). ANOVA analysis confirmed a significant difference between North and South plates which were in treatment tanks (high or low pressures) $\left(\mathrm{F}_{1,22}=4.45\right.$, $p=0.042)$ while South and control plates were not significantly different $\left(\mathrm{F}_{1,22}=0,03, p=0.87\right)$.

It is worth noticing that depending on the origin of the plates and therefore on the type of benthic community, different NIS and other fouling species were found at the end of the experiment. SIMPER analysis showed that on the plates from the South coast, Aiptasia diaphana (average cover percentage $( \pm \mathrm{SE}): 1.26 \pm 0.21)$, Crisia cf. denticulata (1.17 \pm 0.38 ), and Mycale (Carmia) senegalensis $(0.42 \pm 0.14)$, were mostly found among the NIS settled, whereas on plates from the North coast, Polychaetes like

Table 4 Final results of the PERMANOVA analysis of NIS cover on plates

\begin{tabular}{|c|c|c|c|c|c|c|}
\hline Source & df & SS & MS & Pseudo-F & $\mathrm{P}($ perm $)$ & Unique perms \\
\hline Pressure & 2 & 6078.4 & 3039.2 & 4.5666 & 0.003 & 999 \\
\hline Location & 2 & 4325.4 & 2162.7 & 3.2496 & 0.007 & 998 \\
\hline Interaction PresxLoc & 4 & 3562.4 & 890.6 & 1.3382 & 0.192 & 997 \\
\hline \multicolumn{7}{|c|}{ Pairwise test_-propagule pressure } \\
\hline High/Low & & & & & 0.140 & 998 \\
\hline High/Control & & & & & 0.001 & 999 \\
\hline Low/Control & & & & & 0.008 & 999 \\
\hline \multicolumn{7}{|l|}{ Pairwise test-location } \\
\hline South/North & & & & & 0.011 & 998 \\
\hline South/control & & & & & 0.184 & 999 \\
\hline North/control & & & & & 0.007 & 999 \\
\hline
\end{tabular}

Pressure $=$ NIS pressure factor (high, low, ambient). Location $=$ origin of the plate $(\mathrm{N}, \mathrm{S}$, control). Pairwise PERMANOVA for all levels of each factors. Significant results in italics $(p<0.05)$ 


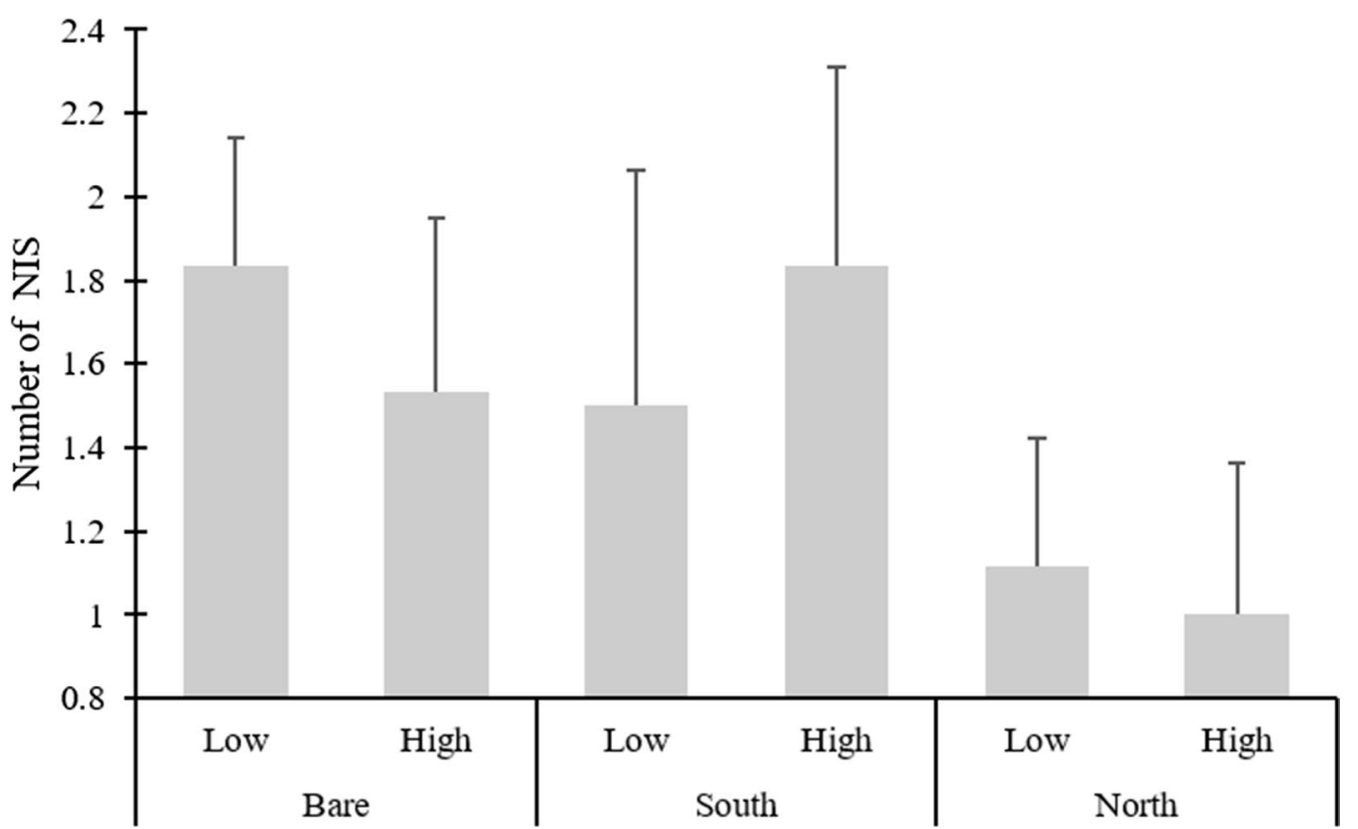

Fig. 4 Average number + SE of NIS $(n=12)$ found attached to the plates at the end of the experiment for both propagule pressure (no NIS found at ambient pressure). Letters $a$ and $b$ indicates values that differ significantly

Salmacina dysteri $(2.36 \pm 0.53)$ and Gastropods from the Vermetidae family $(0.75 \pm 0.36)$ were mainly found.

Finally, in addition to these colonisations, the total composition of the plates was compared between the start and the end of the experiment for all the plates of all treatments (i.e. ambient, low and high) using a nMDS analysis (Fig. 5). Results showed that the total composition of benthic communities shifted during the experiment, resulting overall in more similarities between northern and southern communities. Significant differences were maintained between the two communities at the end of the experiment but in a lesser extent than at the start, and this homogenisation was also observed in the control tanks (ambient pressure). When further investigated by a SIMPER analysis, results showed that there was overall a decrease in native species abundance (Table 5). A two-sample paired t-test confirmed a significant difference between original species abundance between the start and the end of the experiment $(t=2.27$, $\mathrm{df}=8, p=0.032$ ).

\section{Discussion}

The present study has implemented an experimental approach with the aim of evaluating the vulnerability of two benthic communities to NIS colonisation success depending on the propagule pressure applied. To the best of our knowledge, this study represents a pioneer contribution for initiating the characterisation of intertidal communities of Northern and Southern coasts of Madeira. Moreover, in Madeira this study is the first to experimentally examine NIS colonisation process by using complex community arrangements and investigating communities' geographical differences. Overall, our results demonstrated that proximity to a complex fouling community including NIS in the mesocosm caused settlement plates to be colonized by new species, including NIS. Our innovative study design effectively mimicked the introduction of NIS to new environments. Therefore, we suggest this experimental design could be adopted and improved in future studies on propagule pressure.

Propagule pressure, represented here by the quantity of fouling species present in the treatment tank as well as the frequency of introduction of new individuals, did not have a significant impact on the final colonisation success of the plates. Indeed, no difference was observed between the two treatments (i.e. low vs. high), which suggests that, in this case, a low introduction of NIS during a single event was sufficient to induce significant settlement in the benthic communities and that having more individuals and a second introduction did not affect the degree of this settlement. This could indicate that independently of the importance of the vector of introduction (i.e. amount of boats per marina), an urbanised environment would be equally threatened by biological invasions. Similar results have been obtained in other studies $[27,28]$, showing that propagule pressure seems to have a limited impact on NIS settlement in polluted marine habitats compared to other parameters such us abiotic 


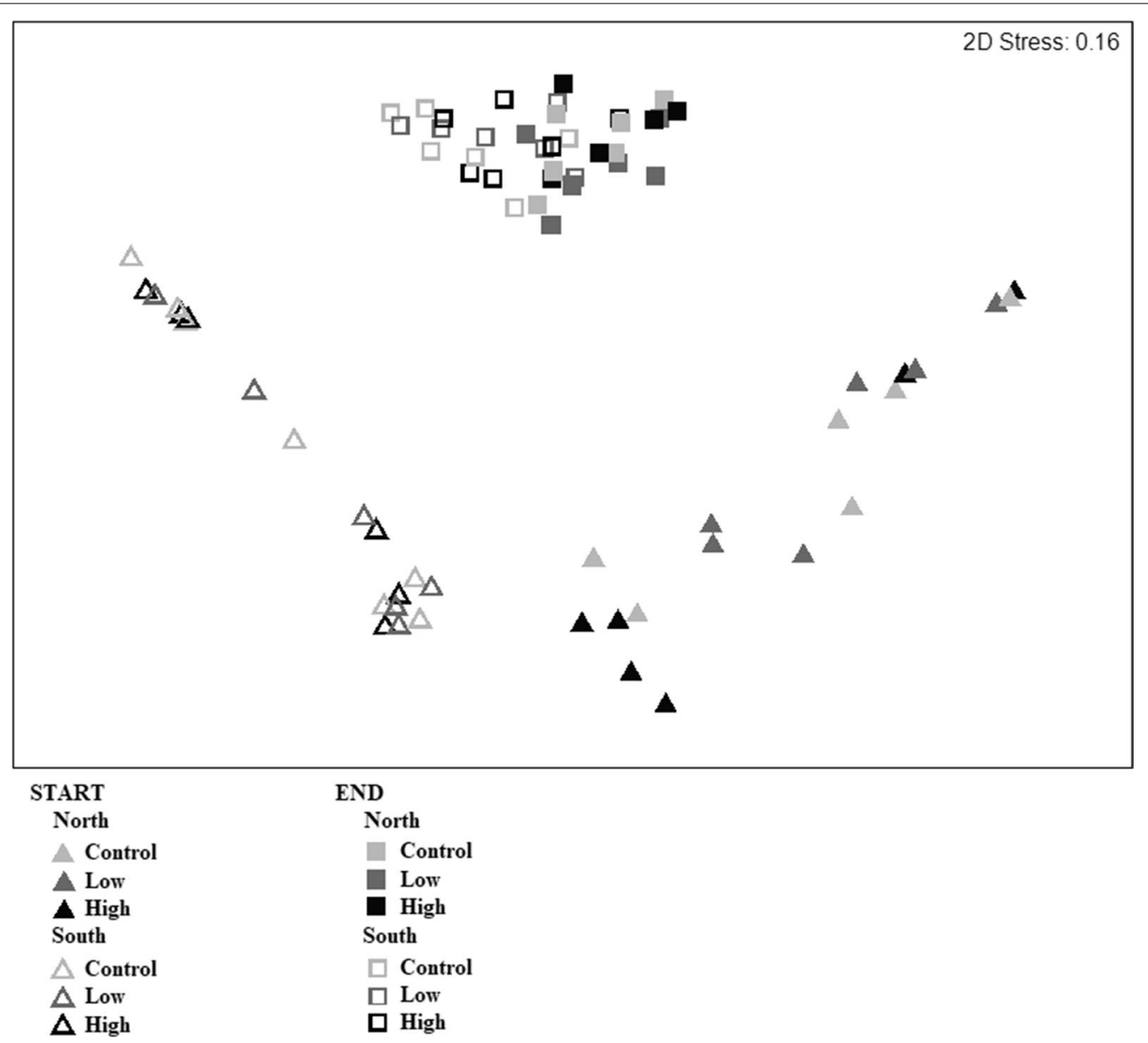

Fig. 5 Non-metric multidimensional scaling (nMDS) plot for the benthic communities' species percentage cover of at the start (filled symbols) and at the end (empty symbols) of the experiment on the PVC plates colonized by from North and South communities, all treatments

Table 5 SIMPER analysis comparing the average abundance of the main species before and after the experiment and their dissimilarities ( $\delta i)$ for all plates and all treatments $(n=36)$

\begin{tabular}{llll}
\hline & Start & End & \\
\hline Species & Av.Abund & Av.Abund & $\delta i$ \\
Lithophyllum incrustans & 22.56 & 21.97 & 16.89 \\
Nematoderma sp. & 28.28 & 17.12 & 14.3 \\
Gelidium turf & 30.73 & 25.14 & 13.6 \\
Polysiphonia sp. & 24.21 & 1.88 & 11.36 \\
Codium adhaerens & 3.39 & 0.05 & 2 \\
Corallina crust (CCA) & 3.17 & 0.79 & 1.74 \\
Padina pavonica & 1.37 & 0 & 0.8 \\
\hline
\end{tabular}

factors (pollutants) or environmental disturbance. In fact, previous studies demonstrated that NIS colonization may be facilitated by habitat disturbance irrespective of differences in NIS supply $[37,57]$. It is interesting to note that under natural conditions, these disturbed habitats and propagule pressures are often conjugated. Another possible interpretation for the non-significance effect of propagule pressure in this experiment is that the two levels of propagule pressure used were not distinct enough in terms of number of individuals introduced and/or frequency of introduction.

The two benthic communities represented in this study showed different responses to invasions, both quantitatively and qualitatively. Quantitatively, the South coast community mainly represented by algae from the Corallinae family and presenting a higher diversity globally received a higher invasion rate than the North coast community characterised by "turf algae" and also by lower diversity. This study tends to support our initial hypothesis as results show that a higher disturbance (here anthropogenic disturbance) could explain the observed difference in fouling colonization. In this context, future research in the island could examine whether the natural environments of the South and North coasts also present 
different quantity of NIS settlement and relate our findings to a larger field observation.

This study also showed that NIS colonisation were qualitatively different (i.e. different species settled) depending on the origin of the plates. This could be explained by the type of biotic surface that each group offers. Plates from the South coast, with mainly CCA, offered a plane surface, as well as the control plates, where species like Aiptasia diaphana (Cnidaria) or Mycale senegalensis (Porifera) will likely be able to settle and spread. In contrast, plates from the North coast with a complex and diverse turf surface offered to e.g. Polychaeta and Bryozoa species such as Crisia sp., by providing an adequate shelter they need to settle. This seems to be in accordance with previous studies where Crisia species are often found in complex and dense environments among various other species [58]. It is interesting to note that bare plates and plates from the South coast showed very similar results. Again, the plane and hard surface offered by CCA seemed to compensate for space saturation, which is usually described as a limiting factor for NIS colonisation $[41,59]$. The colonisation rates have been overall quite low and therefore, further studies should be carried out to further support these results. Due to this low settlement, it was not relevant to use abundance as a parameter to compare results as it has been the case in other studies $[5,60]$. However diversity alone is a commonly used indicator of NIS settlement comparison [59, 61].

In addition, our findings showed that independently from any propagule pressure treatment, the communities at ambient pressure in the control tank were subject to important composition changes, with a total decrease in diversity and abundance of species from the initial communities. This suggests that the mesocosm conditions alone caused major reorganisation in the two benthic communities studied here and that, together with NIS pressure effects, environmental changes highly impacted the succession in benthic communities [24]. This can be attributed to changes in physical and chemical parameters of the sea water used for this experiment which was sourced directly in a medium-sized marina. Water quality analysis showed that water within the marina slightly differed from nearby ocean conditions (i.e. lower salinity, lower $\mathrm{pH}$, absence of wave movement, and presence of pollutants) as it is typically observed in urbanised coastal areas. These results validate the importance of environmental disturbance in the invasion process, and corroborates the findings of similar studies $[23,62,63]$. Additionally, these studies also showed that NIS are less impacted by environmental disturbances than native species due to the rigorous, long-distance transport conditions encountered by NIS to arrive into a new environment. These extreme conditions (e.g. transoceanic voyages on the hulls of ships or on rafts) may have led to the selection of species able to tolerate unfavourable, disturbed and changing environments [28]. For example, in a study published in 2002 [64], Byers refers to the "selection regime alteration" as a theory to explain these results, theory that has been endorsed by other marine scientist since then $[23,28,65]$. This theory states that NIS are "pre-adapted" to survive in recipient environments by nature. Even if propagule pressure seems to have a limited impact, it cannot be ignored that these disturbed environments caused by anthropogenic activities such as urbanised coastlines, will often provide a diversity of vectors causing strong NIS introductions. Therefore, the concurrence of both environmental vulnerability and unmanaged NIS arrival is most likely causing a major threat to coastal ecosystems, threat that can only be mitigated by merging efforts to amplify vector management, by protecting sensitive ecosystems and by further developing our knowledge of complex invasion processes.

Finally, in order to better understand the dynamics at stake during this experiment, the biotic structure of benthic communities from the North and South coasts of Madeira Island would need to be assessed with more detail. The concept of biotic resistance [66] would, for example, be interesting to approach and several questions could be further investigated: are Northern or Southern communities facing different invasion pressure and developed biotic resistance? Are some species in particular involved in resistance mechanisms? As reported in previous studies "biotic resistance can be enhanced when some species reach high levels of dominance" [66, 67]. A similar study could investigate the responses of benthic communities in the absence or presence of some of these key species. Moreover, global environmental parameters of each site, such as currents, wind exposure or sediment load would also need to be further understood to enrich our interpretation of the invasion process, as well as other factors such as habitats complexity and space availability, as these parameters can highly impact invasion success $[10,68,69]$.

In conclusion, it appears that only the factor "origin of the communities" had a significant impact on the final NIS colonisation of the plates representing coastal benthic species. The intensity of propagule pressure did not show significant results and the effect of low and high pressure was similar. Additional studies with greater propagule pressure differences should be carried out in order to confirm the results obtained in this study. Several studies have demonstrated the fragility of coastal ecosystems and the various threats these are facing; urbanisation, pollution, introduction of NIS, among others. The present study represents an additional contribution for this on-going debate by highlighting how 
the identity of species and the overall community composition can be key in determining the success or failure of the settlement process. In this context of intense and unstoppable human pressure on coastal areas globally, this study confirms the relevance of the nature of resident communities facing invasions risks.

\section{Abbreviations}

CCA: crustose coralline algae; NIS: non-indigenous species.

\section{Authors' contributions}

LR led this research work, co-designed and carried-out the experiment, participated in the fieldwork, analysed and interpreted the data obtained, and led the writing of this manuscript. PR helped during all the field work and provided the main author with valuable knowledge on the local environment and on indigenous or non-indigenous species. JCC hosted LR in his lab, provided full support and necessary supervision during the entire study. He conceived and co-designed the experiment. He also offered valuable review of this manuscript. IG closely supervised and advised the entire research work, provided adequate resources. He conceived and co-designed the experiment.. He assisted in all the logistics involved in this study. He also carried-out all the fieldwork necessary and regularly reviewed the writing of this manuscript. All authors read and approved the final manuscript.

\section{Author details}

${ }^{1}$ Faculté des Sciences, Université Montpellier II, Place E. Bataillon, 34095 Montpellier, France. ${ }^{2}$ MARE - Marine and Environmental Sciences Centre, Quinta do Lorde Marina, Sítio da Piedade, 9200-044 Caniçal, Madeira Island, Portugal. ${ }^{3}$ OOM- Oceanic Observatory of Madeira, Agência Regional para o Desenvolvimento da Investigação Tecnologia e Inovação, Edifício Madeira Tecnopolo, Piso 0, Caminho da Penteada, 9020-105 Funchal, Madeira, Portugal. ${ }^{4}$ Department of Oceanography and Fisheries/UAz, Centre of IMAR of the University of the Azores, Rua Prof. Dr. Frederico Machado, 4, 9901-862 Horta, Azores, Portugal. ${ }^{5}$ Smithsonian Environmental Research Center, 647 Contees Wharf Road, Edgewater, MD 21037, USA.

\section{Acknowledgements}

This research was supported by ARDITI - Regional Agency for Development and Technology through their grants toward the Project with reference M1420-09-5369-000001. We are grateful to Quinta do Lorde Hotel and the Observatório Oceânico da Madeira (OOM) for the use of their resources and special thanks to Natacha Nogueira and Carlos Andrade for providing the microalgae supply. This study had the support of Fundação para a Ciência e Tecnologia (FCT), through the strategic project UID/MAR/04292/2013 granted to MARE. J. Canning-Clode was supported by a starting grant in the framework of the 2014 FCT Investigator Programme (IF/01606/2014/CP1230/ CT0001). P. Ramalhosa was partially funded by the Project Observatório Oceânico da Madeira-OOM (M1420-01-0145-FEDER-000001), co-financed by the Madeira Regional Operational Programme (Madeira 14-20), under the Portugal 2020 strategy, through the European Regional Development Fund (ERDF). I. Gestoso was supported by a postdoctoral grant in the framework of the 2015 ARDITI Grant Programme Madeira 14-20 (Project M1420-09-5369-FSE-000001). This work was partially funded by project MIMAR (MAC/4.6.d/066) INTERREG MAC 2014-2020 Programme.

\section{Competing interests}

The authors declare that they have no competing interests.

\section{Availability of data and materials}

The datasets used and/or analysed during the current study are available from the corresponding author on reasonable request.

\section{Consent for publication}

Not applicable.

Ethics approval and consent to participate

Not applicable.

\section{Publisher's Note}

Springer Nature remains neutral with regard to jurisdictional claims in published maps and institutional affiliations.

Received: 30 March 2018 Accepted: 25 September 2018

Published online: 04 October 2018

\section{References}

1. Canning-Clode J. Biological invasions in changing ecosystems:vectors, ecological impacts, management and predictions. Berlin: Springer; 2015.

2. Halpern BS. A global map of human impact on marine ecosystems. Science. 2008;319:948-52.

3. Bellard C, Cassey P, Blackburn TM. Alien species as a driver of recent extinctions. Biol Lett. 2016;12:20150623. https://doi.org/10.1098/ rsbl.2015.0623.

4. García Molinos J, Halpern BS, Schoeman DS, Brown CJ, Kiessling W, Moore PJ, et al. Climate velocity and the future global redistribution of marine biodiversity. Nat Clim Change. 2015;6:83-8. https://doi.org/10.1038/nclim ate2769.

5. Crooks JA. Characterizing ecosystem-level consequences of biological invasions: the role of ecosystem engineers. Oikos. 2002;97:153-66. https ://doi.org/10.1034/j.1600-0706.2002.970201.x.

6. Elton CS. The ecology of invasions by animals and plants. London: Methuen; 1948

7. Valéry L, Fritz H, Lefeuvre JC, Simberloff D. Invasive species can also be native. Trends Ecol Evol. 2009;24:585.

8. Chainho P, Fernandes A, Amorim A, Ávila SP, Canning-Clode J, Castro $J$, et al. Non-indigenous species in Portuguese coastal areas, coastal lagoons, estuaries and islands. Estuar Coast Shelf Sci. 2015;167:199-211.

9. Mack RN. Biotic Invasions: Causes, Epidemiology, Global Consequences, and Control. Bull Ecol Soc Am. 2000;86:249-50. https://doi. org/10.1890/1051-0761(2000)010[0689:BICEGC]2.0.CO;2.

10. Ruiz GM, Freestone AL, Fofonoff PW, Simkanin C. Habitat distribution and heterogeneity in marine invasion dynamics: the importance of hard substrate and artificial structure. 2009; pp. 321-32. https://doi.org/10.1007/ b76710_23.

11. Rabitsch W, Essl F, Genovesi P, Riccardo S. Invasive alien species indicators in Europe-A review of streamlining European biodiversity (SEBI) indicator 10. 2012. https://doi.org/10.2800/64181.

12. Ruiz GM, Fofonoff PW, Carlton JT, Wonham MJ, Hines AH. Invasion of coastal marine communities in North America: apparent patterns, processes, and biases. Annu Rev Ecol Syst. 2000;31:481-531. https://doi. org/10.1146/annurev.ecolsys.31.1.481.

13. Rech S, Borrell Y, Garcia-Vazquez E. Marine litter as a vector for non-native species: what we need to know. Mar Pollut Bull. 2016;113:40-3. https:// doi.org/10.1016/j.marpolbul.2016.08.032.

14. Carlton JT, Chapman JW, Geller JB, Miller JA, Carlton DA, McCuller MI, et al Tsunami-driven rafting: transoceanic species dispersal and implications for marine biogeography. Science. 2017;357:1402-6.

15. Wahl M. Marine epibiosis. I. Fouling and antifouling: some basic aspects. Mar Ecol Prog Ser. 1989;58:175-89.

16. Canning-Clode J, Valdivia N, Molis M, Thomason J., Wahl M. Estimation of regional richness inmarine benthic communities: Quantifying the error. Limnol Oceanogr-Method. 2008;580-90.

17. Railkin A. Marine biofouling: colonization processes and defenses. Boca Raton: CRC Press; 2004

18. Dürr S, Watson DI. Biofouling and antifouling in aquaculture. In: Biofouling. Oxford, UK: Wiley; 2010. pp. 267-87. https://doi.org/10.1002/97814 44315462.ch19.

19. Canning-Clode J, Fofonoff P, McCann L, Carlton JT, Ruiz G. Marine invasions on a subtropical island: fouling studies and new records in a recent marina on Madeira island (Eastern Atlantic Ocean). Aquat Invasions. 2013:8:261-70.

20. Li HX, Orihuela B, Zhu M, Rittschof D. Recyclable plastics as substrata for settlement and growth of bryozoans Bugula neritina and barnacles Amphibalanus amphitrite. Environ Pollut. 2016;218:973-80. https://doi. org/10.1016/j.envpol.2016.08.047. 
21. Kocak F, Ergen Z, Çinar ME. Fouling organisms and their developments in a polluted and an unpolluted marina in the Aegean Sea (Turkey). Ophelia. 1999;50:1-20. https://doi.org/10.1080/00785326.1999.10409385.

22. Bax N, Williamson A, Aguero M, Gonzalez E, Geeves W. Marine invasive alien species: a threat to global biodiversity. Mar Policy. 2003;27:313-23. https://doi.org/10.1016/S0308-597X(03)00041-1.

23. Clark GF, Johnston EL. Propagule pressure and disturbance interact to overcome biotic resistance of marine invertebrate communities. Oikos. 2009:118:1679-86.

24. Rivero NK, Dafforn KA, Coleman MA, Johnston EL. Environmental and ecological changes associated with a marina. Biofouling. 2013;29:803-15.

25. Ashton $\mathrm{G}$. Risk assessment of hull fouling as a vector for marine non-natives in Scotland. Aquat Invasions. 2006;1:214-8. https://doi. org/10.3391/ai.2006.1.4.4.

26. Stachowicz JJ, Fried H, Osman RW, Whitlatch RB. Biodiversity, invasion resistance, and marine ecosystem function: reconciling pattern and process. Ecology. 2002;83:2575-90. https://doi. org/10.1890/0012-9658(2002)083[2575:birame]2.0.co;2.

27. Piola RF, Johnston EL. Pollution reduces native diversity and increases invader dominance in marine hard-substrate communities. Divers Distrib. 2007;14:329-42. https://doi.org/10.1111/j.1472-4642.2007.00430.x.

28. Crooks JA, Chang AL, Ruiz GM. Aquatic pollution increases the relative success of invasive species. Biol Invasions. 2010;13:165-76.

29. Papacostas KJ, Rielly-Carroll EW, Georgian SE, Long DJ, Princiotta SD, Quattrini AM, et al. Biological mechanisms of marine invasions. Mar Ecol Prog Ser. 2017;565:251-68.

30. Lonsdale WM. Global patterns of plant invasions and the concept of invasibility. Ecology. 1999;80:1522. https://doi.org/10.2307/176544.

31. Lockwood $J L$, Cassey P, Blackburn T. The role of propagule pressure in explaining species invasions. Trends Ecol Evol. 2005;20:223-8. https://doi. org/10.1016/j.tree.2005.02.004

32. Drake JM, Baggenstos P, Lodge DM. Propagule pressure and persistence in experimental populations. Biol Lett. 2005;1:480-3. https://doi. org/10.1098/rsbl.2005.0375.

33. Duggan IC, Rixon CAM, Maclsaac HJ. Popularity and propagule pressure: determinants of introduction and establishment of aquarium fish. Biol Invasions. 2006;8:377-82. https://doi.org/10.1007/s10530-004-2310-2.

34. Eschtruth AK, Battles JJ. The importance of quantifying propagule pressure to understand invasion: an examination of riparian forest invasibility. Ecology. 2011;92:1314-22. https://doi.org/10.1890/10-0857.1.

35. Colautti RI, Niimi AJ, Van Overdijk CDA, Mills EL, Holeck K, Maclsaac HJ. Spatial and temporal analysis of transoceanic shipping vectors to the Great Lakes. In: Ruiz GM, Carlton JT, editors. Invasive species Vectors and management strategies. Washington: Island Press; 2008. p. 227-46.

36. Kolar CS, Lodge DM. Progress in invasion biology: predicting invaders. Trends Ecol Evol. 2001;16:199-204.

37. Essink K. General patterns in invasion ecology tested in the Dutch Wadden Sea: the case of a brackish-marine polychaetous worm. Biol Invasions. 2002;4:359-68. https://doi.org/10.1023/A:1023692825663.

38. Ramalhosa P, Nebra A, Gestoso I, Canning-Clode J. First record of the nonindigenous isopods Paracerceis sculpta (Holmes, 1904) and Sphaeroma walkeri Stebbing, 1905 (Isopoda, Sphaeromatidae) for Madeira Island. Crustaceana. 2017;90:1747-64. https://doi.org/10.1163/15685403-00003 727.

39. APRAM, Administração dos Portos da Região Autónoma da Madeira, SA. 2017. http://www.portosdamadeira.com/site/index.php/en. Accessed 6 Jun 2017.

40. Ramalhosa P, Souto J, Canning-Clode J. Diversity of Bugulidae (Bryozoa, Cheilostomata) colonizing artificial substrates in the Madeira Archipelago (NE Atlantic Ocean). Helgol Mar Res. 2016;71:1. https://doi.org/10.1186/ s10152-016-0465-8

41. Gestoso I, Ramalhosa P, Oliveira P, Canning-Clode J. Marine protected communities against biological invasions: a case study from an offshore island. Mar Pollut Bull. 2017;119:72-80. https://doi.org/10.1016/j.marpo Ibul.2017.03.017.

42. Canning-Clode Marine Lab. MIMAR. 2016. http://nutelapat.wixsite.com/ canningclode/copia-mad-momis. Accessed 10 Aug 2017.

43. Canning-Clode J, Souto J, McCann L. First record of Celleporaria brunnea (Bryozoa: Lepraliellidae) in Portugal and in the East Atlantic. Mar Biodivers Rec. 2013;6:e108. https://doi.org/10.1017/S1755267213000821.
44. Caldeira RMA, Groom S, Miller P, Pilgrim D, Nezlin NP. Sea-surface signatures of the island mass effect phenomena around Madeira Island, Northeast Atlantic. Remote Sens Environ. 2002:80:336-60. https://doi. org/10.1016/S0034-4257(01)00316-9.

45. Couvelard X, Caldeira RMA, Araújo IB, Tomé R. Wind mediated vorticitygeneration and eddy-confinement, leeward of the Madeira Island: 2008 numerical case study. Dyn Atmos Ocean. 2012;58:128-49. https://doi. org/10.1016/j.dynatmoce.2012.09.005.

46. Kohler KE, Gill SM. Coral point count with excel extensions (CPCe): a visual basic program for the determination of coral and substrate coverage using random point count methodology. Comput Geosci. 2006;32:125969. https://doi.org/10.1016/j.cageo.2005.11.009.

47. AquaNIS. World Wide Web electronic publication. 2015. www.corpi.ku.lt/ databases/aquanis. Accessed 2 Jul 2017.

48. Katsanevakis S. Building the European Alien Species Information Network (EASIN): a novel approach for the exploration of distributed alien species data. Biolnvasions Rec. 2012;1:235-45.

49. Fofonoff P. National exotic marine and estuarine species information system (NEMESIS). 2014. http://invasions.si.edu/nemesis/. Accessed 2 Jul 2017.

50. Hunter T. The energetics of asexual reproduction: pedal laceration in the symbiotic sea anemone Aiptasia pulchella (Carlgren, 1943). J Exp Mar Bio Ecol. 1984;83:127-47.

51. Watanabe $H$, Charles L. Larva release in response to light by the compound ascidians Distaplia Occidentalis and Metandrocarpa Taylori. Mar Biol Lab Stable. 2016;144:556-66. http://www.jstor.org/stable/1540.

52. Clarke KR. Non-parametric multivariate analyses of changes in community structure. Austral Ecol. 1993;18:117-43. https://doi. org/10.1111/j.1442-9993.1993.tb00438.x.

53. Underwood AJ. Experiments in ecology: their logical design and interpretation using analysis of variance. Cambridge: Cambridge University Press: 1997. https://doi.org/10.1017/CBO9780511806407.

54. Clarke KR, Gorley RN. Primer v6: User Manual/Tutorial. Prim Plymouth 2006

55. Anderson MJ, Gorley RN, Clarke KR. PERMANOVA for PRIMER: quide to software and statistical methods. Plymouth: PRIMER-E; 2008.

56. R Core Computing. R: A Language and Environment for Computing. 2017. https://www.r-project.org.

57. Airoldi L, Bulleri F. Anthropogenic disturbance can determine the magnitude of opportunistic species responses on marine urban infrastructures. PLoS ONE. 2011;6:e22985. https://doi.org/10.1371/journal.pone.0022985.

58. European Topic Centre on Biological Diversity. Habitats type and habitat classification (ETC/BD-EEA). 2008. https://inpn.mnhn.fr/espece/ cd_nom/28557/tab/habitats. Accessed 11 Dec 2017.

59. Hedge LH, Leung B, O'Connor WA, Johnston EL. The interacting effects of diversity and propagule pressure on early colonization and population size. J Anim Ecol. 2014:83:168-75.

60. Vaz-Pinto F, Olabarria C, Gestoso I, Cacabelos E, Incera M, Arenas F. Functional diversity and climate change: effects on the invasibility of macroalgal assemblages. Biol Invasions. 2013;15:1833-46.

61. Colautti RI, Grigorovich IA, Maclsaac HJ. Propagule pressure: a null model for biological invasions. Biol Invasions. 2006:8:1023-37.

62. Leung B, Mandrak NE. The risk of establishment of aquatic invasive species: joining invasibility and propagule pressure. Proc R Soc B Biol Sci. 2007:274:2603-9. https://doi.org/10.1098/rspb.2007.0841.

63. Clark GF, Johnston EL. Temporal change in the diversity-invasibility relationship in the presence of a disturbance regime. Ecol Lett. 2011;14:52-7. https://doi.org/10.1111/j.1461-0248.2010.01550.x.

64. Byers JE. Impact of non-indigenous species on natives enhanced by anthropogenic alteration of selection regimes. Oikos. 2002:97:449-58. https://doi.org/10.1034/j.1600-0706.2002.970316.x

65. Vall-llosera M, Llimona F, de Cáceres M, Sales S, Sol D. Competition, niche opportunities and the successful invasion of natural habitats. Biol Invasions. 2016:18:3535-46. https://doi.org/10.1007/s10530-016-1246-7.

66. Stachowicz JJ. Species diversity and invasion resistance in a marine ecosystem. Science. 1999:286:1577-9. https://doi.org/10.1126/scien ce.286.5444.1577.

67. Harrison S, Cornell H, Grace JB. Retracted: does natural variation in diversity affect biotic resistance? J Ecol. 2015;103:1099-106. https://doi. org/10.1111/1365-2745.12439. 
68. Hedge LH, O'Connor WA, Johnston EL. Manipulating the intrinsic parameters of propagule pressure: implications for bio-invasion. Ecosphere. 2012;3:48. https://doi.org/10.1890/ES11-000375.1.

69. Simkanin C, Davidson IC, Therriault TW, Jamieson G, Dower JF. Manipulating propagule pressure to test the invasibility of subtidal marine habitats. Biol Invasions. 2017;19:1565-75.

70. Neto Al, Cravo DC, Haroun RT. Checklist of the benthic marine plants of the Madeira archipelago. Bot Mar. 2001;44:391-414.

71. Carlton JT, Newman WA, Pitombo FB. Barnacle invasions: introduced, cryptogenic, and range expanding Cirripedia of North and South America. In: Galil BS, Clark PF, Carlton JT, editors. In the wrong placealien marine crustaceans: distribution, biology and impacts. Dordrecht: Springer; 2011. p. 159-213. https://doi.org/10.1007/978-94-007-0591-3_5.

72. Ramalhosa P, Canning-Clode J. The invasive caprellid Caprella scaura Templeton, 1836 (Crustacea : Amphipoda : Caprellidae) arrives on Madeira Island, Portugal. Bioivasions Rec Rec. 2015;4:in press. https://doi. org/10.3391/bir.2015.4.2.05.

73. Goldfuss G. Handbuch der Zoologie. Erste Abtheilung. 1820:1-696.

74. Wirtz P, Canning-Clode J. The invasive bryozoan Zoobotryon verticillatum has arrived at Madeira Island. Aquat Invasions. 2009:4:669-70

75. Ryland JS. Bryozoans (Phyla Bryozoa). In: Hayward PJ, Ryland JS, editors. Handbook of the Marine Fauna of North-West Europe. Oxford: Oxford University Press; 2005. p. 629-62.
76. Ramalhosa P, Souto J, Canning-Clode J. Diversity of Bugulidae (Bryozoa, Cheilostomata) colonizing artificial substrates in the Madeira Archipelago (NE Atlantic Ocean). Helgol Mar Res. 2016;71:1. https://doi.org/10.1186/ s10152-016-0465-8.

77. Ramalhosa P, Camacho-Cruz K, Bastida-Zavala R, Canning-Clode J. First record of Branchiomma bairdi McIntosh, 1885 (Annelida: Sabellidae) from Madeira Island, Portugal (northeastern Atlantic Ocean). Biolnvasions Rec. 2014;3:235-9. https://doi.org/10.3391/bir.2014.3.4.04.

78. Gestoso I, Ramalhosa P, Oliveira P, Canning-Clode J. Marine protected communities against biological invasions: a case study from an offshore island. Mar Pollut Bull. 2016. https://doi.org/10.1016/j.marpo lbul.2017.03.017.

79. Knight-Jones P, Knight-Jones EW. Spirorbidae (Polychaeta) from Madeira including a new species and subgenus of Spirorbis. Mitt Hamb Zool Mus Inst. 1995;92:89-101.

80. Wirtz P. Twelve invertebrate and eight fish species new to the marine fauna of Madeira, and a discussion of the zoogeography of the area. Helgoländer Meeresuntersuchungen. 1998;52:197-207. https://doi. org/10.1007/BF02908748.
Ready to submit your research? Choose BMC and benefit from:

- fast, convenient online submission

- thorough peer review by experienced researchers in your field

- rapid publication on acceptance

- support for research data, including large and complex data types

- gold Open Access which fosters wider collaboration and increased citations

- maximum visibility for your research: over $100 \mathrm{M}$ website views per year

At BMC, research is always in progress.

Learn more biomedcentral.com/submissions 